\title{
PENGARUH PEMBELAJARAN KEWIRAUSAHAAN DAN PRAKTIK KERJA INDUSTRI (PRAKERIN) TERHADAP SIKAP KEWIRAUSAHAAN SISWA SMK NEGERI DI SURABAYA
}

\author{
Raya Sulistyowati, Uninersitas Negeri Surabaya \\ raya_sulistyowati@yahoo.com
}

\begin{abstract}
ABSTRAK
Penelitian ini bertujuan untuk mengetahui pengaruh pembelajaran dan praktik kerja industri kewirausahaan (prakerin) terhadap sikap kewirausahaan pada siswa SMK Negeri Surabaya. Penelitian ini merupakan penelitian kuantitatif. Teknik yang digunakan untuk menguji hipotesis adalah menggunakan analisis regresi. Hasil penelitian yang menunjukkan bahwa nilai koefisien regresi pembelajaran kewirausahaan dan praktik kerja industri berpengaruh signifikan terhadap sikap kewirausahaan siswa SMK Negeri Surabaya, artinya pelaksanaan Prakerin dan pembelajaran kewirausahaan merupakan bagian penting dalam membentuk sikap kewirausahaan siswa SMK Negeri Surabaya.
\end{abstract}

Kata kunci: Kewirausahaan Belajar, Praktik Kerja Industri (Prakerin), Sikap Kewirausahaan

\section{ABSTRACT}

This study aims to Determine the effect of learning and working practices of industrial entrepreneurship (prakerin) on entrepreneurial attitudes in students of SMK Negeri Surabaya. This research is quantitative. The technique used is to test the hypothesis using regression analysis. The results of the study Showed that the value of the regression coefficient of entrepreneurial learning and industry work practices Significantly influence the entrepreneurial attitude of students of SMK Negeri Surabaya, meaning Prakerin implementation and entrepreneurial learning is an important part in shaping the entrepreneurial attitude of students of SMK Surabaya State.

Keywords: Learning Entrepreneurship, Industry Employment Practices, Attitude Entrepreneurship

\section{PENDAHULUAN}

Tantangan pendidikan kejuruan adalah untuk menyiapkan tenaga kerja dalam jumlah dan mutu tertentu sesuai dengan kebutuhan berbagai sektor, khususnya sektor industri dan jasa. Pada era globalisasi yang serba kompetitif di berbagai bidang kehidupan ini tampaknya pendidikan kejuruan menjadi sangat penting, mengingat tuntutan sumber daya manusia di pasaran tenaga kerja yang makin tinggi. Untuk menyiapkan lulusan Sekolah Menengah Kejuruan (SMK) yang memenuhi kualifikasi pasar kerja, maka kompetensi lulusan SMK perlu terus diperbaiki atau ditingkatkan.

Pelaksanaan pendidikan di SMK adalah suatu proses pembelajaran dan bimbingan di sekolah yang ditambah dengan proses pelatihan kerja di dunia usaha 
yang sesungguhnya. Proses pembelajaran di sekolah terutama bertujuan untuk membekali siswa dalam mengembangkan kepribadian, potensi akademik, dan dasar-dasar keahlian yang kuat dan benar melalui pembelajaran program normatif, adaptif, produktif. Program normatif bertujuan membentuk watak dan kepribadian siswa sebagai warga Negara Indonesia, dan adaptif mengenai pembekalan kemampuan untuk mengembangkan diri secara berkelanjutan, sedangkan produktif menyangkut dasar keahlian tertentu untuk bekal kerja. Proses pelatihan kerja di dunia usaha bertujuan untuk membekali siswa menguasai kompetensi keahlian produktif terstandar, menginternalisasi sikap, nilai dan budaya dunia usaha yang berorientasi pada standar mutu, nilai-nilai ekonomi, kritis, produktif dan kompetitif serta sikap kewirausahaan.

Kemampuan kompetensi di atas dapat menumbuh-kembangkan kewirausahaan pada siswa yang melakukan pelatihan, seperti yang diungkapkan Djatmiko (1988) “......bahwa perlakuan untuk mendidik wirausaha pada masa remaja adalah dengan pelatihan kecakapan kerja, sehingga siswa mampu memahami lingkungan kerja yang sesungguhnya dan kompetensi apa saja yang harus dimiliki untuk menjalankan perusahaan. Dari aspek pengetahuan siswa memahami teknik bidang usaha yang dimasuki, peran dan tanggung jawab manajemen dan organisasi bisnis, kepribadian dan kemampuan mandiri, sedangkan aspek keterampilan pada pelatihan meliputi mengatur teknik bidang usaha, keterampilan berkomunikasi, dan berinteraksi. Keterampilan ini memberikan arahan bahwa masalah sulitnya memperoleh pekerjaan dan timbulnya pengangguran tidak hanya diselesaikan dengan satu cara saja tetapi harus dihadapi dengan berbagai pendekatan disiplin keilmuan".

Pendidikan kejuruan pada gilirannya harus mampu berperan dalam mempersiapkan siswa yang mampu bertindak, belajar dan mengatur masa depannya secara aktif dan mandiri. Masalah yang muncul ternyata meskipun para pengambil keputusan pendidikan sudah banyak mengetahui kekurangan yang ada, namun tidak mudah untuk melakukan perubahan pendidikan secara cepat. Tidak mengherankan jika institusi pendidikan kita sepertinya kurang begitu responsif terhadap perkembangan. Sekolah masih berjalan dengan sekedarnya saja mengikuti rutinitas yang ada, tanpa usaha kreatif untuk keluar dari kebiasaan.

Berkaitan dengan masalah pendidikan (SMK) dan adanya permasalahan tingginya jumlah pengangguran dan rendahnya tingkat kompetensi di Indonesia hasil penelitian Sunaryo (2006) yang menunjukan bahwa : Tanggapan dunia industri dalam rangka program link and match pada indikator penyusunan program, penyusunan kurikulum, dan pelaksanaan pendidikan cukup positif dan cenderung bersedia terlibat langsung. Namun, kesediaan industri dalam evalusi dan pemasaran lulusan cenderung rendah. hal ini karena mereka merasa kurang kompeten pada bidang evalusi, sedangkan pemasaran lulusan merupakan suatu masalah rumit karena terjadi ketidakseimbangan antara besarnya lulusan dengan daya tampung dunia industri untuk tenaga kerja.

Salah satu bentuk nyata implementasi kebijakan link and match adalah pelaksanaan Pendidikan Sistem Ganda (PSG) yang pada dasarnya mengandung dua prinsip utama yaitu pertama program bersama (Joint Program) antara SMK dengan industri/perusahaan pasangannya, kedua program pendidikan kejuruan dilakukan di dua tempat, sebagian program yaitu teori dan praktik dasar kejuruan 
dilaksanakan di sekolah (SMK), dan sebagian lainnya dilaksanakan di dunia kerja, yaitu keahlian produktif yang diperoleh melalui kegiatan bekerja di dunia kerja.

Selama ini, praktik kerja memang sudah menjadi salah satu persyaratan kompetensi yang harus dilalui siswa SMK. Sayangnya tidak banyak dunia usaha di dalam negeri yang mau menerima siswa untuk melakukan praktik kerja. Kalaupun ada, praktik kerja yang disediakan sering kali kurang sesuai dengan kompetensi yang dicapai oleh siswa SMK. Padahal dunia usaha dapat menyerap lulusan SMK yang sudah terlatih baik, tanpa perlu mengeluarkan biaya tambahan untuk memberikan pelatihan. Kalaupun ada biaya atau upah tenaga kerja yang harus dikeluarkan, maka besarnya pun tidak sebesar jika mempekerjakan pekerja.

Upaya membekali dan membentuk siswa yang memiliki sikap kewirausahaan melalui pembelajaran kewirausahaan di sekolah dan pelatihan kerja di sektor dunia usaha, sebagai konsep nyata partisipasi masyarakat yang salah satunya adalah masyarakat dunia usaha. Dalam memahami tujuan pendidikan kewirausahaan, optimalisasi dan praktik kerja dalam upaya menumbuhkan sikap kewirausahaan, maka proses pendidikan dan pelatihan tersebut, tidak terlepas dari adanya proses pembelajaran, baik di sekolah maupun di dunia usaha.

Untuk meningkatkan pembentukan sikap kewirausahan diperlukan kerjasama antara pihak sekolah dengan perusahaan (dunia usaha/dunia industri). Penelitian ini dilakukan untuk melihat sampai sejauh mana pengaruh keduanya dalam membentuk sikap kewirausahaan siswa. Dari berbagai pemikiran tersebut di atas, maka penulis mencoba meneliti Pengaruh Pembelajaran Kewirausahaan dan Praktik Kerja Industri (Prakerin) Terhadap Sikap Kewirausahaan Siswa SMK Negeri di Surabaya.

Siswa SMK sebagai sumber daya muda yang sangat potensial dikembangkan dalam bisnis. Siswa SMK adalah sumber daya wirausaha yang sangat melekat dengan dunia usaha dan industri. Bisnis di tingkat persekolahan telah diperkenalkan dalam KOPSIS (Koperasi Siswa), tapi belum mengembangkan perilaku-perilaku ke-wirausahaan dengan baik. Meskipun demikian, siswa-siswa SMK telah dikembangkan cikal-cikal perilaku jujur dan disiplin dalam memenuhi kebutuhan persekolahan. Kejujuran di dalam Wirausaha akan menentukan keberhasilan seseorang untuk maju. Marilah kita tanyakan pada diri sendiri, apakah kita pernah berlaku tidak jujur terhadap orang lain? Bagaimana kita harus berbuat jujur? Sikap dan sifat mental yang jujur akan menghilangkan prasangka dan keresahan hidup. Kejujuran terhadap diri sendiri akan mengubah pandangan dan sikap mental kita.

Agar mampu mengakomodasikan sejumlah tuntutan maka kurikulum SMK diformulasikan menjadi Broad Based Curriculum (BBC) yang struktur hirarkinya dibagi menjadi beberapa komponen atau program yang pada dasarnya dibagi menjadi tiga tahap (Depdiknas, 2002) antara lain Tingkat I berisi kompetensi dan bahan kajian dasar-dasar kejuruan (broad) untuk beberapa keahlian serumpun, sesuai luasan bidang keahlian yang disepakati, Tingkat II berisi kompetensi dan bahan kegiatan yang lebih fungsional untuk menguasai keahlian tertentu, Tingkat III berisi paket paket keahlian (spesialisasi) untuk menguasai kompetensi yang benar-benar fungsional (advance training) untuk melaksanakan pekerjaan tertentu sesuai dengan tuntutan lapangan kerja. 
Begitu pula kurikulum SMK sekarang memasukkan pendidikan perilaku kewirausahaan. Pelajaran kewirausahaan perlu ditanamkan kepada para siswa di sekolah-sekolah, baik diajarkan secara sendirian, disubstitusikan pada sejumlah mata pelajaran yang relevan atau melalui kegiatan bisnis di sekolah melalui "Unit Produksi" (Depdiknas, 2002). Unit ini dikembangkan optimal, sehingga Mampu menghasilkan tambahan pendapatan bagi guru, meningkatkan kemampuan praktik bagi siswa dan guru, dan Penciptaan peluang bisnis bagi sekolah.

Setelah mengenali kepribadian dan kompetensi sendiri, para siswa di sekolah akan mulai Wirausaha dari mana? Akan menunggu petunjuk dari Depnaker? Menunggu izin dari orang tua? Menunggu adanya modal? Menunggu ajakan dari teman-teman sekolah? Menunggu diberi kesempatan? Menunggu datangnya inspirasi dan peluang? Menurut pengalaman Wirausaha, sikap menunggu semacam itu tak ada habis-habisnya. Untuk itu, (Depdiknas, 2002) peranan sekolah dalam rangka menyiapkan calon-calon para Wirausaha di lingkungan sekolah adalah melaksanakan hal-hal antara lain Program pengembangan Broad Based Curriculum, Pengamatan lingkungan persekolahan, Latihan-latihan keWirausahaan di "Unit Produksi" sekolah, Keterampilanketerampilan yang ada hubungannya dengan wirausahawan, Studi banding ke perusahaanperusahaan atau dunia industry, Di mulai dari pelaku sendiri atau dari keyakinan dan kemauan sendiri, Program pelatihan keWirausahaan, Belajar sendiri dengan buku panduan Wirausaha, Diskusikan dan melatih wawancara.

Prakerin pada SMK yang dilaksanakan di dua tempat (lembaga) di sekolah dan dunia industri, maka perlu diadakan program dimana siswa melaksanakan pelatihan di industri. Praktik atau melakukan pelatihan di lapangan merupakan kegiatan yang harus ditempuh oleh siswa dalam bentuk praktik industri pada awal pelaksanaan PSG. Praktik kerja industri atau sering disebut prakerin atau magang menurut Anwar (2004) yaitu Bentuk penyelenggaraan pendidikan keahlian profesional yang memadukan secara sitematik dan sinkron program pendidikan di sekolah dan program penguasaan keahlian yang diperoleh melalui kegiatan bekerja langsung di dunia kerja, terarah untuk mencapai suatu tingkat keahlian profesional tertentu.

Program prakerin dapat dikatakan sukses jika hasilnya dapat mencapai tujuan diadakannya program itu. Untuk dapat menentukan pengalaman seseorang/siswa yang telah melaksanakan praktik industri dapat diukur dengan : (1) lama waktu atau masa kerja dari siswa yang bersangkutan di industri, (2) tingkat pengetahuan dan keterampilan, (3) mempunyai gerakan yang cepat menanggapi tanda-tanda, (4) dapat menduga kemungkinan timbulnya kesulitan dan lebih siap untuk mengatasinya dan (5) melakukan tugasnya tanpa terlalu memusatkan perhatian dan karenanya telah lebih kelihatan tenang.

Jadi praktik kerja industri adalah suatu bentuk pendidikan dan pelatihan yang dilaksanakan di industri atau dunia kerja secara terarah dengan tujuan untuk membekali peserta didik dengan sikap dan keterampilan sesuai dengan cara belajar langsung di industri. Pada dasarnya praktik kerja industri merupakan bagian dari PSG, jadi tujuan dari praktik kerja industri sama dengan tujuan dari PSG yaitu (1) menghasilkan tenaga kerja yang memiliki keahlian profesional, (2) memperkokoh link and match antara sekolah dengan dunia kerja, (3) meningkatkan efisiensi proses pendidikan dan pelatihan tenaga kerja yang 
berkualitas profesional dan (4) memberi pengakuan dan penghargaan terhadap pengalaman kerja yang berkualitas profesional.

Manfaat yang dapat diperoleh dari praktik kerja industri menurut Anwar (2004) antara lain Bagi Siswa yaitu Hasil belajar akan lebih bermakna, karena setelah tamat akan memiliki keahlian profesional sebagai bekal mencari kerja dan mengembangkan diri secara berkelanjutan, Waktu yang diperlukan untuk mencapai keahlian profesional lebih singkat karena telah dilatih pada saat sekolah, Keahlian profesional yang diperoleh dapat mengangkat harga diri dan kepercayaan diri peserta didik yang selanjutnya dapat mendorong mereka untuk meningkatkan keahlian profesionalnya pada tingkat yang lebih tinggi. Sedangkan Bagi Sekolah yaitu Terjaminnya pencapaian tujuan pendidikan untuk memberi keahlian profesional bagi peserta didik, Tanggungan biaya pendidikan menjadi ringan, Terdapat kesesuaian antara program pendidikan dengan kebutuhan lapangan kerja, Memberi keputusan bagi penyelenggara pendidikan. Selanjutnya bagi dunia usaha/dunia industry yaitu dapat mengetahui secara tepat kualitas peserta didik yang belajar dan bekerja di perusahaan, Pada batas-batas tertentu selama masa pendidikan peserta didik tenaga kerja yang dapat memberi keuntungan, Dapat memberi tugas kepada peserta didik untuk mencari ilmu pengetahuan, teknologi dan seni yang relevan, Memberi kepuasan bagi dunia usaha/dunia industri (DU/DI) karena ikut serta menentukan hari depan bangsa.

Pelaksanaan praktik kerja industri diprogramkan secara matang baik mengenai materi pekerjaan (sesuai dengan pekerjaan yang ada di industri/kompetensi maupun alokasi waktu dan kapan pelaksanaannya). Karena praktik kerja industri mengharuskan bekerja di lini produksi (bekerja yang sesungguhnya), maka harus dibekali secara penuh keterampilan dasar. Waktu yang ditempah untuk pelaksanaan praktik kerja industri minimal tiga bulan kerja. Dengan mengikuti minggu dan jam kerja industri kegiatan praktik kerja industri dapat melalui tiga bulan jika dapat memberi nilai tambah bagi industri maupun bagi siswa yang bersangkutan.

Penilaian praktik kerja industri dilakukan pada akhir praktik kerja, siswa memperoleh hasil yang berbentuk nilai prestasi. Prestasi tersebut untuk mengakui kemampuan yang dimiliki oleh siswa dari hasil pengembangan di lapangan. Nilai yang diperoleh siswa harus melalui sistem pengujian yang mengacu pada penguasaan berdasarkan standar tertentu. Dalam praktik kerja industri, siswa mendapatkan nilai dengan kriteria yang telah ditentukan.

Menurut Winardi (2003) pelaku kewirausahaan (entrepreneurship) adalah wirausaha (Entrepreneur) atau wiraswasta: "Entrepreneur berarti orang yang memulai (The Originator) sesuatu usaha bisnis baru. Atau seorang manajer yang berusaha memperbaiki sebuah unit keorganisasian melalui serangkaian perubahan-perubahan produktif".

Apabila berbicara sikap, kita akan dihadapkan pada istilah mental, karena keduanya saling berhubungan. Sikap adalah bagaimana cara kita menghadapi kenyataan. Sedangkan mental adalah perwujudan dari sikap batin seseorang yang akan mendorong tingkah lakunya dalam menghadapi kenyataan, misalnya sikap berani, ulet, dan lain-lain. Menurut Astemoen (2005) menyatakan Bentuk dari sikap diantaranya : 1). berpikiran positif. 2). selalu optimis. 3). mampu menghadapi risiko apapun. 4). mempunyai motivasi yang tinggi terhadap pencapaian prestasi. 
Secara ringkas Meredith, Musselman, dan Sumanto dalam Suryana, (2003) mengemukakan beberapa ciri sekaligus sebagai sikap kewirausahaan, yaitu:1). Keingin an yang kuat untuk beridiri sendiri.2), kemampuan untuk mengambil risiko. 3). kemampuan untuk belajar dari pengalaman. 4). memotivasi diri sendiri. 5). semangat untuk bersaing. 6). orientasi pada kerja keras. 7). percaya pada diri sendiri. 8). dorongan untuk berprestasi. 9). tingkat energi yang tinggi. 10). tegas. 11). yakin pada kemampuan diri sendiri. Sumanto menambahkan ciri lain : 12). tidak suka uluran tangan dari pemerintah/pihak lain di masyarakat. 13). tidak tergantung pada alam dan berusaha untuk tidak menyerah pada alam. Ditambahkan pula oleh Meredith : 14). kepmimpinan. 15). keorsinilan. 16). berorientasi ke masa depan, dan penuh gagasan.

Kegiatan yang dilakukan adalah studi referensi awal yang bertujuan untuk mendapatkan temuan-temuan relevan dari hasil-hasil penelitian sebelumnya. Terdapat beberapa hasil penelitian yang memiliki relevansi dengan penelitian ini yaitu: Slamet (2004). Hasil studi kasus pelaksanaan pendidikan sistem ganda (PSG) di tiga sekolah model terstandar (STM Negeri 4 Medan, STM Pembangunan Surabaya, dan STM Negeri Krawang) dengan analisis kualitatif. (Mamiek Slamet, 2004). Dengan keterkaitan yang erat dan kesepadanan yang serasi akan menghasilkan mutu lulusan Sekolah Menengah Kejuruan yang memiliki kemampuan Profesional Tingkat Menengah sesuai dengan kebutuhan dunia kerja.

Selanjutnya Wena (1997) hasil penelitian tentang "pemanfaatan industri sebagai sumber belajar dalam pendidikan sistem ganda (Made wena, 1997). Sebagai sumber belajar yang dimanfaatkan, industri merupakan tempat belajar yang sangat penting dalam program PSG. Adanya kerjasama tersebut menuntut pihak sekolah bersama pihak industri harus terlibat dalam perencanaan, pelaksanaan, dan evaluasi program PSG. Agar usaha kerjasama tersebut terwujud tentu harus diperhatikan beberapa hal, yang berkaitan dengan; (1) kemampuan pihak sekolah dalam melakukan pengembangan kurikulumnya; (2) berlangsungnya kegiatan proses belajar mengajar pada dua tempat yaitu di sekolah dan di industri secara berkesinambungan; dan (3) tersedianya instruktur industri yang memahami dan mampu melaksanakan kegiatan pendidikan ataupun pembelajaran. Ketiga komponen tersebut merupakan prasyarat bagi keberhasilan pelaksanaan program PSG, dalam memanfaatkan sumber belajar di sekolah dan sumber belajar di industri.

Kemudian Hartini (2002) Evaluasi Program Madrasah Aliah Keagamaan (studi kasus di Madrsah Aliyah Negeri 1 Evaluasi Program Pendidikan Sistem Ganda Surakarta) Riset Sri Hartini (2002) dengan model Stake dengan hasil penelitian menunjukkan pada input (5 aspek) yang dievaluasi secara rasional kelimanya dapat terpenuhi dengan standar yang telah ditetapkan, demikian juga proses ( 5 aspek) dan output ( 2 aspek) disimpulkan terpenuhi.

Selanjutnya Mulyadi (2010) melalui penelitiannya bahwa (1) analisis deskriptif menunjukkan bahwa secara umum: (a) Pendidikan dan Latihan telah dilaksanakan dengan baik; (b) Sikap Kewirausahaan terbentuk secara lebih positif setelah mendapatkan Diklat; dan (c) Perilaku kewirausahaan mahasiswa peserta PMW UPI sudah tinggi; (2) Pendidikan dan Latihan berpengaruh positif dan signifikan terhadap sikap kewirausahaan mahasiswa peserta PMW UPI. Dalam hal ini, aspek proses pembelajaran merupakan aspek yang paling tinggi 
dibandingkan aspek-aspek lainnya, sedangkan aspek Kemampuan Instruktur dipersepsi paling rendah; (3) Pendidikan dan Latihan (Diklat) dan sikap kewirausahaan secara langsung maupun melalui Sikap Kewirausahaan berpengaruh positif dan signifikan terhadap perilaku kewirausahaan mahasiswa peserta PMW UPI. Dalam hal ini, aspek Percaya Diri dan aspek Berorintasi ke masa depan dan prestatif pada merupakan aspek yang paling tinggi dibandingkan aspek-aspek lainnya, sedangkan aspek Pengambilan Risiko dipersepsi paling rendah. Pada variabel Perilaku Kewirausahaan, aspek Keuangan merupakan aspek yang paling tinggi dibandingkan aspek-aspek lainnya, sedangkan aspek Pemasaran dipersepsi paling rendah.

Penelitian tentang pengembangan model pembelajaran internalisasi nilainilai kewirausahaan pada SMK di kota Malang dilakukan oleh Agung Winarno (2009). Penelitian ini dengan menghasilkan beberapa kesimpulan diantaranya adalah kecenderungan sikap atau nilai-nilai kewirausahaan yang dimiliki siswa berdasarkan hasil tes menunjukkan angka yang relatif belum optimal hal ini mengindikasikan bahwa sikap kewirausahaan siswa belum terbentuk dengan baik. Model pembelajaran yang digunakan guru, hasil penelitian juga menunjukkan minimnya variasi dan tidak banyak yang menyentuh penggunaan model yang mengarah pada pembentukan nilai-nilai (afeksi).

Penelitian yang dilakukan oleh Adeyemi (2009) tentang keterkaitan atau hubungan faktor-faktor guru dengan pencapaian belajar siswa pada pelajaran sosial di Nigeria. Faktor-faktor yang terkait dengan guru ini diantaranya adalah tingkat penilaian guru dalam gaya menilai, gaya penilaian guru, serta karakteristik personal guru yaitu kualifikasi, pengalaman mengajar dan gaya mengajar. Penelitian yang menganalisis mean, standar deviasi, serta uji regresi berganda menghasilkan kesimpulan bahwa faktor guru terbukti secara meyakinkan mempunyai keterkaitan kuat dengan pencapaian belajar siswa. Selanjutnya dalam penelitian tersebut dijelaskan bahwa lamanya mengajar seorang guru serta kualifikasi pendidikannya mempunyai kontribusi yang meyakinkan terhadap pencapaian belajar siswa. Menariknya justru guru-guru muda dengan pengalaman mengajar yang baru beberapa tahun mempunyai profesionalisme pengajaran yang lebih baik dibandingkan dengan guru yang sudah lama mengajar.

Andrew dan Peter (2003) melakukan penelitian tentang karaktersitik guru dan tingkat pencapaian siswa. Temuan dari penelitian ini adalah adanya keterkaitan antara karakteristik guru dengan tingkat pencapaian belajar siswa. Penelitian yang dilakukan oleh Will Dobbie (2011) di Amerika juga menghasilkan kesimpulan yang serupa. Sedangkan penelitian yang dilakukan oleh Douglas N. Harris dan Tim R. Sass (2006) menghasilkan kesimpulan bahwa profesionalisme guru mempunyai hubungan yang positif terhadap pencapaian belajar siswa. Kesimpulan selanjutnya menunjukkan bahwa pengalaman guru juga berpengaruh positif pada efektifitas pembelajaran.

Penelitian yang dilakukan oleh Koesmiyati (2007) berkesimpulan bahwa meskipun terdapat beberapa faktor yang saling mempengaruhi terbentuknya kepribadian siswa, tetapi dijumpai pula faktor-faktor yang mendorong terbentuknya kepribadian siswa, antara lain adanya guru yang berperan aktif dalam membentuk kepribadian siswa di sekolah. Sedangkan penelitian yang dilakukan oleh Pihie dan Sani (2009) di Malaysia menghasilkan salah satu kesimpulan yaitu model pembelajaran berpusat pada siswa dengan pendekatan 
pengarahan kewirausahaan memungkinkan siswa untuk memiliki pola pikir kewirausahaan yang positif.Selanjutnya Acikgoz (2005) menyimpulkan bahwa karakteristik guru mempunyai pengaruh penting pada pembentukan karakter siswanya, hal ini diperkuat oleh Saghafi dan Shatalebi (2012) serta Lumpkin (2008) yang menyatakan bahwa proses pendidikan karakter pada dasarnya berawal dari guru dan berakhir pada siswa. Dengan demikian peran guru menjadi sangat penting dan tidak dapat dipisahkan dalam proses pendidikan karakter.

Penelitian berikutnya dilakukan oleh Howard dan Barbara (2003). Penelitian ini menyimpulkan bahwa pendidikan kewirausahaan dapat mempengaruhi karakteristik kewirausahaan umum di kalangan pelajar tingkat menengah. Secara khusus, siswa dengan pelatihan kewirausahaan secarakeseluruhan memiliki karakteristik kewirausahaan yang lebih besar, motivasi berprestasi yang lebih tinggi, kontrol pribadi lebih baik, dan harga diri mempunyai lebih besar daripada kelompok pembanding.

Mubadi dan Saptono, Jiwa Kewirausahaan Siswa SMK : Suatu Survei Pada 3 SMK Negeri dan \& SMK Swasta Di DIY. Jiwa kewirausahaan siswa SMK di DIY relatif sudah cukup tinggi. Adanya perbedaan jiwa kewirausahaan siwa ditinjau dari pekerjaan orang tua, latar belakang keluarga, proses pendidikan dan pelatihan, serta program keahlian di SMK.

\section{METODE PENELITIAN}

Penelitian ini merupakan penelitian dengan pendekatan kuantitatif. Untuk penelitian kuantitatif, data penelitiannya berupa data kuantitatif yaitu data yang dapat diukur sehingga dalam pengujian hipotesisnya menggunakan analisis inferensial (Kountur, 2005). Dalam penelitian ini memiliki dua variabel bebas yaitu Pembelajaran Kewirausahaan $\left(\mathrm{X}_{1}\right)$, Praktik Kerja Industri $\left(\mathrm{X}_{2}\right)$, dan satu variabel terikat yaitu Sikap Kewirausahaan (Y).

Populasi penelitian ini adalah siswa kelas XI SMK Negeri 1, SMK Negeri 4, dan SMK Negeri 10 di Surabaya dengan Bidang Studi Keahlian Bisnis dan Manajemen, Program Studi Keahlian Tata Niaga, Kompetensi Keahlian Pemasaran. Teknik yang digunakan dalam pengambilan sampel dalam penelitian ini adalah teknik stratified random sampling dengan menentukan sejumlah total 116 sampel dari jumlah populasi akses.

Data yang digunakan dalam penelitian ini yaitu data primer. Adapun data primer, yaitu data yang diperoleh langsung dari responden yakni Dalam penelitian ini terdapat 3 angket, yaitu angket pembelajaran kewirausahan, angket praktik kerja industri (prakerin), dan angket sikap kewirausahaan siswa. Teknik analisis data yang digunakan dalam penelitian ini menggunakan analisis regresi berganda.

\section{HASIL PENELITIAN DAN PEMBAHASAN}

\section{Hasil Penelitian}

Untuk variabel $\mathrm{X}_{1}$ ( Pembelajaran Kewirausahaan) Dari rata-rata responden untuk angket Pembelajaran Kewirausahaan sebesar 4.6 menunjukkan bahwa Pembelajaran Kewirausahaan tergolong sedang. Standart deviasi untuk angket Pembelajaran Kewirausahaan sebesar 2,196. Angka deviasi ini menunjukkan bahwa Pembelajaran Kewirausahaan cukup homogen. 
Untuk variabel $\mathrm{X}_{2}$ (Praktik Kerja Industri/Prakerin). Dari rata-rata jawaban responden menunjukkan bahwa Praktik Kerja Industri (Prakerin) sebesar 4.7 menunjukkan bahwa tingkat Praktik Kerja Industri (Prakerin) tergolong sedang. Stadart deviasi untuk angket Praktik kerja Industri (Prakerin) sebesar 6.308. Angka standart deviasi ini menunjukkan bahwa jawaban responden semakin heterogen.

Untuk variabel Y (sikap kewirausahaan siswa SMK Negeri di Surabaya). Data rata-rata sikap kewirausahaan siswa SMK Negeri di Surabaya sebesar 4.8 menunjukkan bahwa sikap kewirausahaan SMK Negeri di Surabaya tergolong tinggi. Standar deviasi untuk variabel sikap kewirausahaan SMK Negeri di Surabaya mencapai 2.48 angka standart deviasi cukup tinggi dan lebar ini menunjukkan bahwa mencapai nilai sikap kewirausahaan siswa SMK Negeri di Surabaya heterogen.

Berdasarkan pengujian data yang dilakukan diperoleh persamaan regresi sebagai berikut :

$$
Y=-0,115+0,164 X_{1}+0,854 X_{2}
$$

Dari persamaan tersebut nilai konstanta sebesar -0,115 menunjukkan besarnya pengaruh pembelajaran kewirausahaan $\left(\mathrm{X}_{1}\right)$ dan Praktik Kerja Industri (Prakerin) $\left(\mathrm{X}_{2}\right)$ apabila variabel bebas tersebut tidak berubah, maka diprediksikan sikap kewirausahaan sebesar $-0,115$ satuan. Koefisien regresi untuk pemebelajaran kewirausahaan $\left(\mathrm{X}_{1}\right)$ sebesar 0,164 . Berarti jika pemebelajaran kewirausahaan $\left(\mathrm{X}_{1}\right)$ naik sebesar 1 satuan, maka sikap kewirausahaan (Y) akan mengalami kenaikan sebesar 0,164 satuan, dengan anggapan variabel bebas lainnya tetap. Lebih lanjut koefisien regresi untuk prakerin $\left(\mathrm{X}_{2}\right)$ sebesar 0,854 . Berarti jika prakerin $\left(\mathrm{X}_{2}\right)$ naik sebesar 1 satuan, maka hasil belajar (Y) akan mengalami peningkatan sebesar 0,854 satuan, dengan anggapan variabel bebas lainnya tetap.

Berdasarkan uji yang telah dilakukan terlihat nilai $\mathrm{F}_{\text {hitung }}=8,560$ dengan nilai signifikan $\mathrm{p}=0,000$ lebih kecil dari 0,05 , sehingga dapat disimpulkan hipotesis nihil yang berbunyi : tidak ada pengaruh yang signifikan antara Pembelajaran Kewirausahaan $\left(\mathrm{X}_{1}\right)$ dan Praktik Kerja Industri $\left(\mathrm{X}_{2}\right)$ terhadap Sikap Kewirausahaan Siswa SMK Negeri di Surabaya (Y) ditolak.

Penelitian ini membuktikan bahwa ada pengaruh yang sangat signifikan antara Pembelajaran Kewirausahaan dan Praktik Kerja Industri (Prakerin) terhadap Sikap Kewirausahaan Siswa SMK Negeri di Surabaya.

Hasil Koefisien determinasi berganda R Square menunjukkan Bahwa Sikap Kewirausahaan Siswa SMK Negeri di Surabaya dipengaruhi oleh Pembelajaran Kewirausahaan dan Praktik Kerja Industri (Prakerin) sebesar 0,132 (13,20\%). Sedangkan 86,80\% Variabel Sikap Kewirausahaan Siswa SMK Negeri di Surabaya dipengaruhi oleh faktor-faktor lain.

Berdasarkan hasil perhitungan korelasi parsial diperoleh nilai beta $\mathrm{X}_{1}$ sebesar $-0,101$ dimana $p=0,366$ dan $X_{2}$ sebesar 0,417 dimana $p=0,000$ yang artinya sangat signifikan karena lebih kecil dari 0,05 . Artinya ada pengaruh yang signifikan secara parsial Antara Pembelajaran Kewirausahaan $\left(\mathrm{X}_{1}\right)$ dan Praktik Kerja Industri (Prakerin) $\left(\mathrm{X}_{2}\right)$ terhadap Sikap Kewirausahaan Siswa SMK Negeri di Surabaya (Y). Berdasarkan hasil perhitungan juga menunjukkan bahwa sumbangan efektif Pembelajaran Kewirausahaan $(-0,085)^{2}$ sebesar 0,0072 (0,72\%) dimana $\mathrm{p}=0,366$. Sedangkan sumbangan efektif Praktik Kerja Industri (Prakerin) 
yaitu $(0,331)^{2}$ sebesar $0,1095(10,95 \%) \mathrm{p}=0,000$. Artinya adalah variabel Praktik Kerja Industri (Prakerin) secara sangat signifikan dominan mempengaruhi variabel dependen Sikap Kewirausahaan Siswa SMK Negeri di Surabaya, karena memiliki sumbangan efektif paling besar yaitu 10,95\% dan nilai Beta 0,417.

\section{Pembahasan}

\section{Pengaruh Pembelajaran Kewirausahaan Terhadap Sikap Kewirausahaan Siswa SMK Negeri di Surabaya}

Berdasarkan tabulasi data responden didapatkan bahwa responden lebih banyak menyatakan ragu-ragu dan tidak setuju dibandingkan menyatakan setuju pada penyataan "metode pembelajaran kewirausahaan sangat menarik sehingga dapat menumbuhkan minat terhadap kewirausahaan". Hal ini menunjukkan guru belum menerapkan pembelajaran aktif, inovatif, kreatif, efektif, dan menyenangkan. Untuk dapat meningkatkan pembentukan sikap kewirausahaan maka metode pembelajaran disaran untuk lebih bervariatif dan menarik siswa.

Secara keseluruhan hasil penelitian menunjukkan bahwa pengaruh pembelajaran kewirausahaan bisa meningkatkan prestasi belajar siswa . Dengan demikian bahwa terdapat pengaruh yang positif dan signifikan pembelajaran kewirausahaan terhadap sikap kewirausahaan siswa kelas XII Pemasaran SMK Negeri Kota Surabaya. Semakin tinggi pembelajaran kewirausahaan dilaksanakan, maka akan semakin tinggi sikap kewirausahaan siswa. Sebaliknya semakin rendah pembelajaran kewirausahaan, maka akan semakin rendah pula sikap kewirausahaan siswa.

Hasil ini menunjukkan bahwa sikap siswa kewirausahaan dipengaruhi oleh pengalaman pribadi siswa. Pengalaman pribadi adalah pengalaman belajar kewirasusahaan. Pengalaman belajar yang mendalam bukan ditunjukkan oleh lamanya belajar, melainkan intensitas interaksi dalam belajar, dan terjadi transfer belajar dalam diri siswa (Gordon, 2008). Interaksi belajar kewirausahaan di sekolah, bukan hanya hubungan antara guru dan siswa, tetapi terjadinya interaksi antara siswa dengan materi pelajaran kewirausahaan dan pelajaran itu bermakna bagi siswa. Suatu pelajaran akan bermakna jika dalam proses belajarnya dapat melibatkan emosi siswa. Adanya interaksi mendalam antara siswa dengan pelajaran kewirausahaan diharapkan akan membentuk sikap positif siswa terhadap kewirausahaan. Faktor lain yang berperan dalam pembentukan sikap kewirausahaan ialah guru, karena guru merupakan salah satu sumber pengaruh perubahan sikap ke arah positif. Merger mengidentifikasi tiga peristiwa yang mempengaruhi sikap terhadap kewirausahaan, yaitu : (1) kondisi, (2) konsekuensi, dan (3) peniruan (modeling). Guru harus mampu menciptakan kondisi belajar yang menyenangkan bagi siswa. Guru harus menciptakan pengalaman belajar yang menyebabkan konsekuensi menyenangkan bagi siswa, dan guru merupakan model bagi siswa.

Selain itu, penelitian menunjukkan bahwa keberhasilan pengajaran kewirausahaan di sekolah menengah kejuruan, ditandai oleh adanya perubahan pada komponen pengetahuan (kognitif), sikap (afektif), dan keterampilan (psikomotor). Ini berarti bahwa selain ranah kognitif, komponen sikap merupakan indikator untuk mengukur keberhasilan siswa setelah menyelesaikan program pembelajaran. Dengan demikian keberhasilan pengajaran kewirausahaan di sekolah menengah kejuruan dapat diukur melalui indikator yaitu bagaimana sikap 
siswa terhadap kewirausahaan. Mengacu pada pengertian sikap sebagai suatu kecenderungan untuk memberikan reaksi terhadap objek tertentu, yang terdiri dari komponen: kognitif, afektif, dan konatif, serta pengertian kewirausahaan sebagai pekerjaan yang sifatnya mandiri yang merupakan objek sikap, maka hakikat sikap siswa terhadap kewirausahaan adalah ekspresi opini siswa terhadap pekerjaan yang sifatnya mandiri. Sikap siswa SMK terhadap kewirausahaan dapat diukur dan diamati melalui tanggapannya (positif atau negatif) terhadap aspek kewirausahaan, yaitu: (a) sifat, persyaratan, dan suasana kerja kewirausahaan, terdiri dari: bekerja mandiri, bertanggung jawab, berorientasi tujuan dan prestasi, percaya pada kemampuan diri, berani mengambil resiko, kemauan bekerja keras dan tekun, jujur dan dapat dipercaya, serta disiplin; (b) manfaat atau kegunaan kewirausahaan, yang berhubungan dengan penghasilan dan kehormatan atau harga diri.

\section{Pengaruh Praktik Kerja Industri (Prakerin) Terhadap Sikap Kewirausahaan Siswa Kelas XII Pemasaran SMK Negeri Kota Surabaya}

Berdasarkan tabulasi data responden didapatkan bahwa responden lebih banyak menyatakan setuju dan sangat setuju dibandingkan menyatakan setuju. Hal ini menunjukkan bahwa indikator kesiapan dunia usaha / industri (DUDI) yaitu : (1) Komitmen kerjasama dengan SMK; (2 ) SKNI (Standard Kompetensi Nasional Indonesia); (3) Sarana dan fasilitas, instruktur / pembimbing di industri; dan (4) Manajemen industri telah cukup terpenuhi. Pada penyataan "sumber materi magang memadai dalam pendalaman dan pemperluas wawasan dan Instruktur jujur dalam melaksanaakan evaluasi prakerin". Hal ini menunjukkan bahwa sumber materi yang berasal dari materi pembelajaran di sekolah perlu penyesuaian dengan materi praktik kerja industri (prakerin). Dunia industri cepat berkembangan sesuai dengan perkembangan teknologi, idealnya sumber materi pembelajaran di sekolah juga turut sejalan dengan perkembangan terkini sehingga sumber materi praktik kerja industri (prakerin) tidak tertinggal. Untuk dapat meningkatkan pembentukan sikap kewirausahaan maka disarankan sumber materi praktik kerja industri (prakerin) perlu ditambah dengan materi terkini.

Selain itu juga terdapat pada tabulasi data responden didapatkan bahwa responden lebih banyak menyatakan setuju dan sangat setuju dibandingkan menyatakan ragu-ragu pada penyataan "Instruktur jujur dalam melaksanakan evaluasi magang". Hal ini dapat terjadi, karena instruktur memiliki pengetahuan dalam membuat alat evaluasi dengan baik dan benar. Untuk meningkatkan pembentukan sikap kewirausahaan, maka instruktur lebih obyektif dalam menilai, Dalam membuat evaluasi yang obyektif sudah dibuatkan kisi-kisi penilaian sehingga instruktur dapat menilai dengan berpedoman pada kisi-kisi tersebut.

Secara keseluruhan hasil penelitian menunjukkan bahwa pengaruh pelatihan kerja industri (prakerin) bisa meningkatkan (karena nilainya positif) prestasi belajar dan wawasan siswa dalam berwirausaha, dengan demikian bahwa terdapat pengaruh yang positif dan signifikan pelatihan kerja industri terhadap sikap kewirausahaan siswa SMK Negeri di Surabaya. Semakin tinggi praktik kerja industri (prakerin) dilaksanakan, maka akan semakin tinggi sikap kewirausahaan siswa.

Dengan demikian menunjukkan bahwa pelatihan adalah suatu proses pembelajaran terhadap seseorang atau kelompok untuk meningkatkan kemampuan atau perilaku (penetahuan, skill dan sikap) untuk mencapai tujan-tujuan tertentu 
yang diinginkan. Dalam melaksanakan proses pembelajaran pelatihan kerja di dunia usaha tidak terlepas dari berbagai komponen pembelajaran yang meliputi : tujuan, bahan ajar, metoda, alat dan sumber serta evaluasi (Djamarah dan Zain, 1995). Namun dalam kaitannya dengan keberhasilan proses pembelajaran tidak terlepas dari komponen istruktur di lingkungan dunia usaha di mana siswa melakukan praktik kerja industri (prakerin). Hal ini sejalan dengan apa yang dikemukakan oleh Bhattacharya dan Mandke (1992) untuk mencapai keberhasilan pembelajaran tersebut, maka harus diciptakan keadaan yang saling menguntungkan dan hubungan triangular interaktif antara instruktur, siswa dan pihak industri.

Selain itu penelitian menunjukkan proses praktik kerja industri (prakerin) di dunia usaha/ industri bertujuan untuk membekali siswa menguasai kompetensi keahlian produktif terstandar, menginternalisasi sikap, nilai dan budaya dunia usaha yang berorientasi pada standar mutu, nilai-nilai ekonomi, kritis, produktif dan kompetitif serta sikap kewirausahaan.

Kemampuan kompetensi di atas dapat menumbuh-kembangkan kewirausahaan pada siswa yang melakukan pelatihan, seperti yang diungkapkan Djatmiko : ".....bahwa perlakuan untuk mendidik wirausaha pada masa remaja adalah dengan pelatihan kecakapan kerja, sehingga siswa mampu memahami lingkungan kerja yang sesungguhnya dan kompetensi apa saja yang harus dimiliki untuk menjalankan perusahaan. Dari aspek pengetahuan siswa memahami teknik bidang usaha yang dimasuki, peran dan tanggung jawab manajemen dan organisasi bisnis, kepribadian dan kemampuan mandiri, sedangkan aspek keterampilan pada pelatihan meliputi mengatur teknik bidang usaha, keterampilan berkomunikasi, dan berinteraksi. Keterampilan ini memberikan arahan bahwa masalah sulitnya memperoleh pekerjaan dan timbulnya pengangguran tidak hanya diselesaikan dengan satu cara saja tetapi harus dihadapi dengan berbagai pendekatan disiplin keilmuan". (Djatmiko,1988).

Selanjutnya penelitian menunjukkan bahwa keberhasilan praktik kerja industri (prakerin) kerja di dunia usaha/ industri yang dilakukan oleh siswa SMK ini tidak terlepas dari peran instruktur pelatihan di lingkungan industri, seperti apa yang dikemukakan oleh Bhattacharya dan Mandke (1992) bahwa "pada pelaksanaan pembelajaran di industri instrukturlah yang akan paling bertanggung jawab terhadap keberhasilan belajar". Adapun keterkaitannya dengan pembentukan sikap kewirausahaan, instruktur memiliki peran yang penting sebagai orang yang berarti khusus atau orang lain yang dianggap penting (significant others) yang akan memperngaruhi pembentukan sikap. Hal ini sejalan dengan apa yang dikemukakan oleh Saifuddin (1955) bahwa "salah satu faktor yang dapat mempengaruhi pembentukan sikap adalah pengaruh orang lain yang dianggap penting". Pemahaman ini dapat diartikan bahwa sikap sikap terbentuk karena adanya interaksi sosial yang dialami individu interasi sosial yang dialami siswa pada pelatihan kerja di industri adalah interaksi antara siswa dengan instruktur sebagai orang yang akan mempengaruhi pembentukan sikap siswa.

\section{Pengaruh Pembelajaran Kewirausahaan Dan Praktik Kerja Industri (Prakerin) Terhadap Sikap Kewirausahaan Siswa SMK Negeri Di Surabaya}

Pengaruh pembelajaran kewirausahaan sebesar $0,72 \%$ dan praktik kerja industri (prakerin) sebesar10,95\% . Dari persamaan tersebut juga dapat diartikan 
bahwa setiap peningkatan pembelajaran kewirausahaan sebesar 1 persen, maka akan meningkatkan (karena nilainya positif) prestasi belajar sebesar0,72\%, dan setiap peningkatan praktik kerja industry (prakerin) sebesar 1 persen, maka akan meningkatkan (karena nilainya positif) prestasi belajar sebesar 10,95\%. Nilai koefisien regresi praktik kerja industri (prakerin) besar dibandingkan koefisien regresi untuk variabel pembelajaran kewirausahaan, artinya praktik kerja industri (prakerin) lebih menentukan (pengaruh) lebih besar terhadap sikap kewirausahaan siswa SMK Negeri di Surabaya dibandingkan variabel pembelajaran kewirausahaan.

Hasil penelitian menunjukkan bahwa (1) analisis deskriptif menunjukkan bahwa secara umum: (a) Pembelajaran Kewirausahaan telah dilaksanakan dengan katagori tinggi; (b) Praktik Kerja Industri (Prakerin) telah dilaksanakan dengan katagori sangat tinggi; dan (c) Sikap kewirausahaan siswa SMK Negeri di Surabaya sudah dikatagorikan sangat tinggi; (2) Pembelajaran Kewirausahaan dan Pelatihan kerja berpengaruh positif dan signifikan terhadap sikap kewirausahaan siswa SMK Negeri di Surabaya. Dalam hal ini praktik kerja industri (prakerin) mempunyai efek lebih tinggi pembelajaran kewirausahaan.

Berkaitan dengan hasil penelitian yang menunjukkan bahwa Nilai koefisien regresi praktik kerja industri (prakerin) lebih tinggi dibandingkan koefisien regresi untuk variabel pembelajaran kewirausahaan, artinya praktik kerja industri (prakerin) lebih menentukan (pengaruh) lebih tinggi terhadap sikap kewirausahaan dibandingkan variabel pembelajaran kewirausahaan, hal ini juga dapat dilihat dari hasil penelitian Sunaryo yang menunjukan bahwa Tanggapan dunia industri dalam rangka program link and match pada indikator penyusunan program, penyusunan kurikulum, dan pelaksanaan pendidikan cukup positif dan cenderung bersedia terlibat langsung. Namun, kesediaan industri dalam evalusi dan pemasaran lulusan cenderung rendah.hal ini karena mereka merasa kurang kompeten pada bidang evalusi, sedangkan pemasaran lulusan merupakan suatu masalah rumit karena terjadi ketidak seimbangan antara besarnya lulusan dengan daya tampung dunia industri untuk tenaga kerja. (Sunaryo, 2002)

Selama ini, praktik kerja industri (prakerin) memang sudah menjadi salah satu persyaratan kompetensi yang harus dilalui siswa SMK. Sayangnya, tidak banyak dunia industry di dalam negeri yang mau menerima siswa untuk melakukan praktik kerja industri (prakerin). Kalaupun ada, praktik kerja yang disediakan sering kali kurang sesuai dengan kompetensi yang dicapai oleh siswa SMK. Padahal dunia usaha dan industri dapat menyerap lulusan SMK yang sudah terlatih baik, tanpa perlu mengeluarkan biaya tambahan untuk memberikan pelatihan. Kalaupun ada biaya atau upah tenaga kerja yang harus dikeluarkan, maka besarnya pun tidak sebesar jika mempekerjakan pekerja.

Penelitian ini menunjukkan proses pembelajaran di sekolah merupakan pembelajaran yang ditujukan untuk memberikan pemahaman secara teoritis kewirausahaan melalui pelajaran kewirausahaan pemahaman secara praktik baik melalui unit produksi maupun Koperasi Sekolah atau Bisnis Center. Sedangkan faktor lainnya adalah lingkungan keluarga. Terbentuknya sikap kewirausahaan pada diri siswa juga dipengaruhi oleh bagaimana orang tua memaknai nilai-nilai yang baik, yang merupakan cerminan perilaku kewirausahaan, seperti yang diungkapkan oleh Soemanto (1993) bahwa penerapan nilai-nilai serta potensi kewirausahaan yang baik harus sudah dimulai di lingkungan keluarga. Kedua 
faktor di atas, pada penelitian ini merupakan faktor yang tidak diukur dengan suatu pemahaman bahwa kedua faktor tersebut terletak pada tingkatan pemahaman dan motivasi saja. Sedangkan aktualiasai dari pemahaman dan motovasi ini dilaksanakan pada suatu proses pembelajaran pelatihan kerja, sebab dengan pelatihan kerja siswa dituntut untuk kerja keras, inovatif serta kreatif serta menginternalisasikan nilainilai kewirausahaan dan pemahaman serta keterampilan dalam kehidupan yang sebenarnya.

Seperti yang diungkapkan Yoesoef dalam Danuharnimedjo (1998) bahwa untuk membentuk sikap kewirausahaan adalah dimulai dengan tahapan pemahaman teori, studi kasus, dan pemberian motivasi, ketiga tahapan ini dapat dilakukan di sekolah. Sedangkan tahap keempat adalah praktik kerja industri (prakerin), yaitu belajar melalui perbuatan sesuatu, sebab keliru untuk menganggap bahwa segala sesuatu yang perlu di ketahui dalam hidup ini dapat di ajarkan melalui pendidikan di lingkungan sekolah saja. Artinya siswa harus berusaha mencarinya sendiri dan menemuinya dalam praktik kehidupan yang sebenarnya. Dan melalui praktik kerja industri (prakerin) siswa ditempa untuk memahami lingkungan kerja yang sebenarnya.

\section{KESIMPULAN}

Berdasarkan hasil analisis dan pembahasan dapat ditarik kesimpulan bahwa Praktik Kerja Industri (Prakerin) telah dilaksanakan dengan kategori sangat tinggi, demikian juga pembelajaran kewirausahaan. Sedangkan sikap kewirausahaan siswa SMK Negeri di Surabaya dikategorikan sangat tinggi. Secara rinci antara lain (1) Pembelajaran kewirausahaan berpengaruh terhadap sikap kewirausahaan pada siswa SMK Negeri di Surabaya. Ini berarti semakin tinggi persepsi pelaksanaan pembelajaran kewirausahaan dilaksanakan, maka cenderung semakin tinggi sikap kewirausahaan siswa. (2) Praktik Kerja Industri (Prakerin) berpengaruh terhadap sikap kewirausahaan pada siswa SMK Negeri Kota Surabaya. Ini berarti semakin tinggi persepsi pelaksanaan pelatihan kerja, maka cenderung semakin tinggi sikap kewirausahaan siswa. (3) Pembelajaran kewirausahaan dan Praktik Kerja Industri (Prakerin) berpengaruh terhadap sikap kewirausahaan pada siswa SMK Negeri di Surabaya. Ini berarti semakin tinggi dan semakin baik pembelajaran kewirausahaan serta praktik kerja industri (prakerin), maka cenderung semakin tinggi sikap kewirausahaan siswa SMK Negeri di Surabaya. Hasil penelitian ini secara umum menyimpulkan bahwa hubungan antara pembelajaran kewirausahaan dan Praktik Kerja Industri (Prakerin) dan terhadap sikap kewirausahaan terdapat hubungan fungsional linear positif searah. Hal ini membawa implikasi bahwa untuk memprediksikan pembentukan sikap kewirausahaan siswa SMK Negeri di Surabaya harus diperhitungkan besaran variabel-variabel tersebut secara sendiri-sendiri (tunggal) maupun bersama-sama (ganda).

\section{DAFTAR RUJUKAN}

Ahmadi, Abu H \& Nur Uhbiyati. (2001) Ilmu Pendidikan. Jakarta: Rineka Cipta. Anwar. (2004). Pendidikan Kecakapan Hidup Konsep dan Aplikasi. Bandung : Alfabeta 
Arikunto, Suharsini. (1992). Prosedur Penelitian: Suatu Pendekatan Praktis. Jakarta: Rineka Cipta

Arikunto, Suharsini. (2000). Manajemen Peneltian, Jakarta : Rineka Cipta

Astamoen,M.P. (2005). Entrepreneurship dalam perspektif kondisi bangsa Indonesia. Bandung:Alfabeta

Azwar, Saifuddin. (1995) Sikap Manusia Teori dan Pengukurannya.Yogyakarta: Pustaka Pelajar

Chardiwich, Bruch. A, Hormard M Bahr, Stan L Albrecht. (1991). Sosial Science Research Mehtod. New Jersey. Englewood Cliffts.

Danuhadimedjo, Djatmiko. (1998). Kewirausahaan dan Pembangunan. Bandung : Alfabeta.

Depdikbud, (1994). Konsep Sistem Ganda Pada SMK di Indonesia. Direktorat Jenderal Pendidikan Dasar dan Menengah Departemen Pendidikan dan Kebudayaan. Jakarta: Dit. Dikmenjur,

Depdikbud, (1997). Keterampilan Menjelang 2020 Untuk Era Global. Jakarta: Dit.. Dikmenjur,

Depdikbud,(2002) Pokok-Pokok Pikiran Pengembangan Pendidikan Kejuruan Menjelang 2020. Jakarta: Dit. Dikmenjur.

Dewey, John, (2002). Pengalaman dan Pendidikan. Terjemahan John de Santo. Yogyakarta: Kepel Pres,

Djamarah, S.B. (2002). Psikologi belajar. Jakarta: PT Rineka Cipta.

Djatmiko Danuhadimodjo, (1988). Kewiraswastaan dan Pembangunan : Bandung : CV.Alfabeta,

Djauharis, R. (1997) Perbaikan Sistem Pendidikan Sekolah Kejuruan dalam melaksanakan PSG. Jurnal Pendidikan dan Kebudayaan, Th. III No. 010, September.

Mapa (1994). Pengembangan Sumber Daya Manusia: Melalui Sekolah Menengah Kejuruan (SMK). Jakarta: PT Balai Pustaka,.

Furqon. (1997). Statistik Terapan untuk Penelitian. Bandung : Alfabeta

Ghozali, Imam. (2001). Aplikasi Analisis Multivariate Dengan Program SPSS.

Semarang: Badan Penerbit Universitas Diponegoro.

Ghozali, Imam. (2005). Aplikasi Analisis Multivariate Dengan Program SPSS. Semarang : UNDIP

Hadi, Suhartono. (1989). Statistik 1. Yogyakarta: Andi Offset

Hamalik, Oemar. (2004) Proses Belajar Mengajar. Jakarta: PT Bumi Karsa,.

Hamali, (2000), Pendidikan Tenaga Kerja Nasional : Bandung : PT. Citra Aditya.

Hartini, Sri. (2002) Evaluasi Program Madrasah Aliyah Keagamaan di Madrasah Alyah Negeri 1, Yogyakarta: Tesis, PPs Universitas Negeri Yogyakarta,.

Kasan, Thalib. (2003) Administrasi Pendidikan Teori dan Aplikasi, Jakarta: Studio Pres,.

Kerlinger. (1990). Asas-asas Penelitian Behavior (Alih Bahasa) Semarang. IKIP Semarang

Komarudin dan Yooke Tjuparmah. (2000). Kamus Istilah : Karya Tulis Ilmiah. Jakarta : Bumi Aksara.

Lupiyoadi, Rambat dan Jero Wacik (1998), Wawasan Kewirausahaan: Cara Mudah Menjadi Wirausaha. Jakarta : FE.UI. 
Malik, Oemar H. (1990). Pendidikan tenaga kerja nasional, kejuruan, kewiraswastaan, dan manajemen. Bandung: PT. Citra Aditya Bhakti.

Mar'at (1984). Sikap Manusia Perubahan Serta Pengukurannya. Jakarta Galia Indonesia.

Meredith, Geoffrey G., Et. Al., 2000, Kewirausahaan; Teori dan Praktek, terjm. Andre Asparsayogi, Pustaka Binaman Pressindo, Jakarta

Mulyadi, Hari (2010) Pengaruh Pendidikan Dan Latihan, Magang Terhadap Sikap Dan Motivasi Kewirausahaan Serta Implikasinya Pada Perilaku Kewirausahaan Mahasiswa. Desertasi UPI. Bandung.

Mulyasa,(2004), Kurikulum Berbasis Kompetensi, Konsep, Karakteristik dan Implementasi. Penerbit PT. Remaja Rosdakarya Offset - Bandung.

Peraturan Pemerintah No. 28 Tahun 1990.

Peraturan Pemerintah No. 29 Tahun 1990

Pidarta, Made. (1988). Landasan Kependidikan. Jakarta : Rineka Cipta

Sidi, Djati Indra. (2001) Mепији Masyarakat Belajar. Jakarta: Paramadina, Logos Wacana Ilmu,

Singarimbun, Masri dan Sofyan Effendi. (1989). Media Penelitian Survai. Jakarta : LP3ES

Slamet. (1990). Pondasi pendidikan kejuruan. Lembaran perkuliahan. Yogyakarta: $\quad$ Pascasarjana IKIP Yogyakarta.

Slavin, R. E. (1994). Educational Psychology Theory Into Practices. 4th ed. Boston: Ally and Bacon Publishers.

Soedijarto (1998).Pendidikan Sebagai Sarana Reformasi Mental dalam Upaya Pembangunan Bangsa. Jakarta: Balai Pustaka

Soedijarto, (2008) Landasan dan Arah Pendidikan Nasional Kita. Jakarta: PT Media Indonesia

Soemanto, Wasty, (1984), Pendidikan Wirausaha (Sekuncup Ide Profesional), Bina Aksara, Malang

Natawidjaja, (1988). Kiat Mengentaskan Pengangguran Melalui Wirausaha. Bandung : Bumi Aksaara

Sugiono. (2006). Metode Penelitian Kualitatif, Kuantitatif dan $R \& D$. Bandung: Alfabeta.

Sunaryo, et al. (2002) Sejarah Pendidikan Teknik dan Kejuruan di Indonesia, Direktorat Pendidikan Menengah Kejuruan (Dit. Dikmenjur): Jakarta

Sumahamijaya, Suparman, 1980. Membina Sikap Mental Wiraswasta, Gunung Jati, Jakarta.

Sujana, H.D. (1996). Penelitian Luar Sekolah : Wawasan Sejarah Perkembangan Falsafah dan Teori Pendukung Asas. Bandung : Nusantara Press

Sudjana, N. (2001). Dasar-dasar Proses Belajar Mengajar. Bandung: Sinar Baru Algessindo.

Sudjana. (2002). Metode Statistika. Bandung : Tarsito

Sudjana. (2003). Teknik Analisis Regresi dan Korelasi (Bagi Para Peneliti).

Sudjana. (2004). Manajemen Program Pendidikan. Bandung : Fala Production.

Sugiyono, (2000) Statistik Untuk Penelitian, Bandung : Alfabeta,

Suhadi Sigit, (1980) Mengembangkan Kewiraswastaan, Yogyakarta : UGM,

Sumanto. (1995). Metodologi Penelitian Sosial dan Pendidikan. Yogyakarta : Andi Offset. 
Supranto, J. (2000). Statistic Teori dan Alikasi. Jakarta : Erlangga

Suryana (2006), Kewirausahaan, Pedoman Praktis, Kiat dan Proses Menuju Sukses, Jakarta: Salemba empat

Sutikno, M.Sobry, (2004) Menuju Pendidikan Bermutu. Mataram: NTP Press,

Tarmudji, Tarsis. (2000). Prinsip-prinsip Wirausaha. Yogyakarta : Liberty

Undang-Undang Nomor 20 Tahun 2003 tentang Sistem Pendidikan Nasional. Jakarta: Departemen Pendidikan Nasional.

Usman, Husaini dan R. Purnomo Setiady Akbar (1995). Pengantar Statistika. Jakarta : Bumi Aksara

Usman, Husein. (1988), Manajemen Teori, Praktik dan Riset Pendidikan, Penerbit Buku Aksara, Jakarta.

Wena, Made. (1996). Pendidikan Sistem Ganda. Bandung : Tarsito

Wibowo, Jatmiko Alexander. (2002). Pendidikan Berbasis Kompetensi: Belajar dari Dunia Kerja, Yogyakarta: Universitas Atma-Jaya,

\section{Jurnal :}

Engel, James F., David T. Kollat, and Roger D. Blackwell, (2001). Consumer Behavior (http://crm,hct,ac,ae,2012)

Brotosiswoyo, Suprapto. (1991, Agustus). Pendidikan menengah. Makalah Pengantar Diskusi Kelompok Rapat Kerja Nasional. Jakarta: Depdikbud.

Hadi, Winanto Dwi. "Menengok Pendidikan Kejuruan di Republik Federasi German (FRG)", Jurnal Pendidikan dan Kebudayaan Th.IV No. 13, Juni 1998

Joesoef, (1976) enterpreunership (http://cntpr,doht,ac,ae,2012)

Samani, Muchlas. (1992). Keefektifan program pendidikan STM: Studi penelitian pelacakan terhadap lulusan STM rumpun mesin tenaga dan teknologi pengerjaan logam di Kotamadya Surabaya tahun 1986 dan 1987. Disertasi doktor IKIP Jakarta, 1992.

Semiawan, Cony R. (1991, Januari). Pengembangan kirikulum untuk SMKTA menyongsong era tinggal landas. Makalah pada seminar pengembangan kurikulum PMK. Jakarta: Balitbang Dikbud.

Slamet, Mamiek. "Hasil Studi Kasus Pelaksanaan Sistem Ganda", Jurnal Pendidikan Nasional, edisi khusus, 2004., Hasil Studi Kasus Pelaksanaan Pendidikan

Sistem Ganda (PSG) Di Tiga Sekolah Model Standar: STM Negeri 4 Medan, STM Pembangunan Surabaya, dan STM Karawang Dengan Analisis Kualitatif, Jurnal Pendidikan dan Kebudayaan, Th IV, No. 013, Juni 1998.

Suherman. (1998). Pengaruh Pelatihan Kerja Terhadap Kinerja Pamong Belajar. Tesis. Program Pascasarjana UPI Bandung : tidak diterbitkan

Tilaar, H.A.R. (1991, September). Sistem pendidikan yang modern bagi pembangunan masyarakat industri modern berdasarkan Pancasila. Makalah pada KIPNAS V, Jakarta

Walgito (2001) Pengembangan Kewirausahaan di Indonesia. (http://wrh,cct,atc,etl,2012)

Wena, Made. (1997). "Pemanfaatan Industri Sebagai Sumber Belajar dalam Pendidikan Sistem Ganda", Jurnal Pendidikan dan Kebudayaan. Th. III, No. 010 September 
Winardi, (2003). Gagasan Pokok Pendidikan Sistem Ganda di Lima Sekolah Menengah Kejuruan, (PSG-5 SMK). Jurnal Pendidikan dan Kebudayaan, Th. IV, No. 013, Juni 1998.

Yuyun Wirasasmita, (2000).“Tenaga Kerja Pengangguran Bertambah”. Jakarta: Kompas. 